\title{
Geochemical Characteristics of Metamorphic Rock-Hosted Gold Deposit At Onzon-Kanbani Area, Central Myanmar
}

\author{
Aung Tay Zar ${ }^{1,3, *}$, I Wayan Warmada ${ }^{1}$, Lucas Donny Setijadji ${ }^{1}$, Koichiro Watanabe ${ }^{2}$ \\ ${ }^{1}$ Department of Geological Engineering, Faculty of Engineering, Gadjah Mada University, Yogyakarta, Indonesia \\ ${ }^{2}$ Department of Earth Resources Engineering, Faculty of Engineering, Kyushu University, 744 Motooka, Nishi-ku, Fukuoka 819-0395, Japan
} ${ }^{3}$ Department of Geology, Pyay University, Pyay, Myanmar

\author{
* Corresponding author : aungtayzar99@gmail.com \\ Tel.:+62-81-329-747-974 \\ Received: June 16, 2017. Revised : July 1, 2017, Accepted: Aug 20, 2017, Published: 1 Sept 2017 \\ DOI : 10.24273/jgeet.2017.2.3.410
}

\begin{abstract}
Onzon-Kabani area is located on the western border of generally N-Strending Mogoke M etamorphic Belt. Many artisanal and small-scale gold mines were noted sincelast three decades. Gold mineralization is mainly hosted in marble and occasionally observed in gneiss. Host rocks chemistry is mainly controlled by hydrothermal activities and regional metamorphism. The compatible elements of host rocks are relatively more mobile than incompatible elements during alteration and deformation. Variety of plutonic rocks such as leucogranite, syenite and biotite granite are intruded into older metamorphic rocks. In ACF diagram, leucogranite and syenite are placed in S-type granite field and biotite granite occupied in I-type granite field. Mineralization is observed as fracture filling vein and less amount of disseminated nature in marble unit. Mineralogically, gold areassociated with other base metal such as pyrite, galena, sphalerite, and chalcopyrite. Hydrothermal alteration hal os are developed as a narrow zone in the peripheral of hydrothermal conduits from proximal to distal; 1) silicic, 2) sericite-illite, and 3) propylitic alteration. In place, silicic altered zone is rich in $\mathrm{SiO}_{2}, \mathrm{Al}_{2} \mathrm{O}_{3}$, and $\mathrm{K}_{2} \mathrm{O}$. Moreover, concentrations of $\mathrm{S}, \mathrm{Cu}, \mathrm{Zn}$, and $\mathrm{Pb}$ are more than any other alteration zones. The $\mathrm{CaO}$ is gradually increase to least altered zone where wt\% of loss of ignition (LOI)also increase significantly to least-altered samples (marble). Some fluid boiling characteristics of vein textures and fluid inclusion petrography are al so observed in hydrothermal system of research area. The homogenization temperature ( Th) of quartz vein samples are $159^{\circ} \mathrm{C}$ to $315^{\circ} \mathrm{C}$ and salinity are 0.88 to 12.51 wt\%of $\mathrm{NaCl}$ equivalent. This research focused to describe the geochemical characteristics of metamorphic rock-hosted gold deposit in Onzon-Kanbani area.
\end{abstract}

Keywords: Mogok Metamorphic Belt, Fracture filling vein, Hydrothermal alteration, Fluid boiling

\section{Introduction}

Gold and associated base metal mineralization at Onzon-Kanbani areais located in Thabeikkyin Township, Mandalay region, central Myanmar. This area is west $85 \mathrm{~km}$ faraway from well known Mogok Township (ruby land), Myanmar. Small scale local gold rush and abundant artisanal working were started since last thirty years ago. This area is alsoa part of Mogok Metamorphic Belt(Searle and Haq, 1964)which famous for their precious and semiprecious gem stones production and distinct geological feature. Mineralization is mostly hosted in marble unit and occasionally in gneiss.It is observed as fracture filling veins and minor disseminated nature in marble. Generally, gold mineralization in Mogok Metamorphic Belt is inferred as orogenic gold (Mitchell et al., 2004) but locally epithermal and skarn gold mineralization are also spread along this belt (Myint et al., 2014). The main objective of this paper writing is not onlyto describethe geochemical characteristics of metamorphic rock-hosted gold deposit but also to understand the deposit genesis of research area.

\section{Methods of study}

Totally, fifty ofthin and polished sections of altered rocks and ore sampleswere conducted for mineralogical study by optical microscope and confirmed again by scanning electron microscopy with energy-dispersive X-ray (SEM-EDX). Additionally, X-ray Diffraction (XRD) analysis for the hydrothermal alteration minerals that were done for both bulk rock (random powder) and clay fraction. Major and trace elements analyses were carried out on representative samples using XRF and inductively coupled plasma optical emission spectroscopy (ICP-OES).Moreover, quartz samples were collected from mineralization veins to conduct fluid inclusion study. Double polished quartz wafers were prepared for these quartz veins where the thickness of wafers varied between 150 and $300 \mu \mathrm{m}$. Microthermometric measurements were done using Linkam THMSG600 combined 
heating and freezing stage, attached to Nikon petrographic microscope with Axiovision software. All of these laboratory analyses were made in Department of Earth Resource Engineering, Mineral Resource lab, Kyushu University, Japan.

\section{Regional geologic setting}

Myanmar is tectonically complex region and composed with micro plates such as Sibumasu, West Burma, and India. Along a tectonic history is built by repeatedly occurring subduction, accretion and collision events. These events chiseled the geological landform and metallogenic provinces in Myanmar. Traditionally, the territory of Myanmar is subdivided into (1) the India plate to the west, (2) Burma microplate (West Burma) in the central part and (3) Shan-Thai block (Sibumasu) 'east of the Sagaing fault' (Fig. 1).

Mogok Metamorphic Belt is one of the distinct geological and metallogenic province in Myanmar and located between Central low-land (West Burma) and Shan-Thai block (Sibumasu). It is believed that southern continuation of Himalaya (Searle and Haq, 1964)and formed by either collision (Mitchell, 1979) or strike-slip movement (Metcalfe, 2009). In this place, well-known right lateral strike-slip fault, Sagaing Fault (Swe, 1972)is served as awestern boundary. Alternatively, thestructural configuration of this area is closely related to this fault.Mogok Metamorphic Belt is composed of Paleozoic to Mesozoic meta-carbonate rocks andmetapelite where avariety of CretaceousPalaeogene plutonic igneous rocks(Barley et al., 2003; Mitchell, 1979; Mitchell et al., 2012)are intruded to older rocks. East of this belt, Shan
Plateau (Sibumasu) is a topographic high with anaverage elevation of about $1000 \mathrm{~m}$ and mainly composed of a series of Ordovician-Triassic carbonate rocks and continental sedimentary rocks (Jurassic?). The western margin of Mogok Metamorphic Belt is juxtaposed with Central lowland (West Burma) which is filled by Eocene to PlioQuaternary sediments.

\section{Geology of Onzon-Kanbani area}

Onzon-Kanbani area is a part of Mogok Metamorphic Belt. Therefore, mainly composed with metamorphic and igneous rocks which are exposed with differing areal coverage (Fig.2).Metamorphic rocks of research area such as avariety of marbles, calc-silicate rocks and gneiss are widely distributed in eastern and western part. The age of the protolith of metasedimentary was originally considered Precambrian (Bender, 1983), but Permian fossils in marble near Kyaukse (Thein and Win, 1969)indicate that Carboniferous to Triassic ageis more likely. Alternatively, igneous units are generally covered the middle part of the research area and found as fitful. The older metamorphic rocks are intruded by granite and syenite. The main igneous intrusion of the research area is biotite granite also called as "Kabaing Granite". The age of magmatism in the Mogoke Metamorphic Belt ranged that magmatism of leucogranite and syenite melt took place in Eocene time during the regional metamorphism and then Kabaing granite intruded the country rocks of the study area in Miocene after regional metamorphism (Barley et al., 2003).

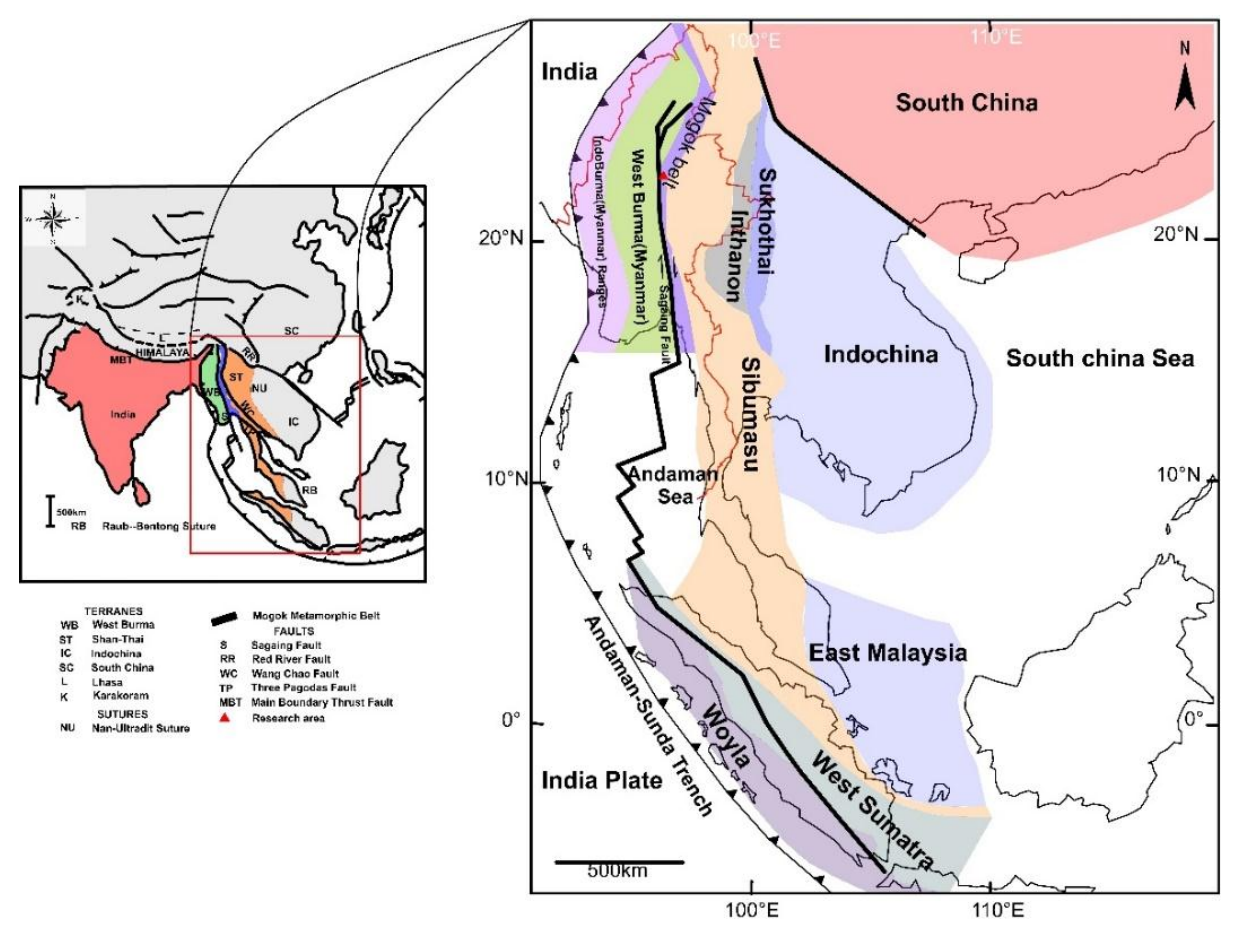

Fig.1. Map showing geologic setting of Mogok Metamorphic Belt and its environ. Modify after(Barley et al., 2003) 


\section{Petrography}

The dominant metamorphic rocks in OnzonKanbani area which is composed of meta-carbonate rocks (marbles and calc-silicate rock) and biotite gneiss. Heterogeneous igneous intrusions are observed the middle part of the area where diopside calc-silicate rock occur along the margin of igneous intrusions (Fig. 2).

Marble unit appears white (fresh) and dark gray to pale greenish (weathered) in color. The foliated nature also occurs in some marbles (thin foliated marble and diopside marble) and calc-silicate rock. Gneiss unit is medium-crystalline, banded and gneissose with finer and coarser portion. Weathered color light grayand dark gray of fresh surface indicate that abundance of biotite and hornblende in gneiss. In igneous rocks, leucogranite and syenite are observed as small intrusive bodies intruded to marble units. Light to pinkish color appearance of outcrops arecharacteristic feature. Biotite granite is a one of important plutonic rock in research area. It has dark grey to yellowish color weathered surface and light grey offresh surface. The exfoliation nature is common textural feature.

Microscopic observation shows a variety of minerals in marble and gneiss. In marble unit, diopside, phlogopite, calcite are main constituents whereas biotite, plagioclase and quartz are dominant in gneiss. Some of the minerals are believed that the products of regional metamorphism related with India-Asia collision. In syenite and leucogranite, felsic color minerals are mainly observed such as quartz, plagioclase, muscovite and nepheline. The common minerals of biotite granite are quartz, biotite, plagioclase and orthoclase

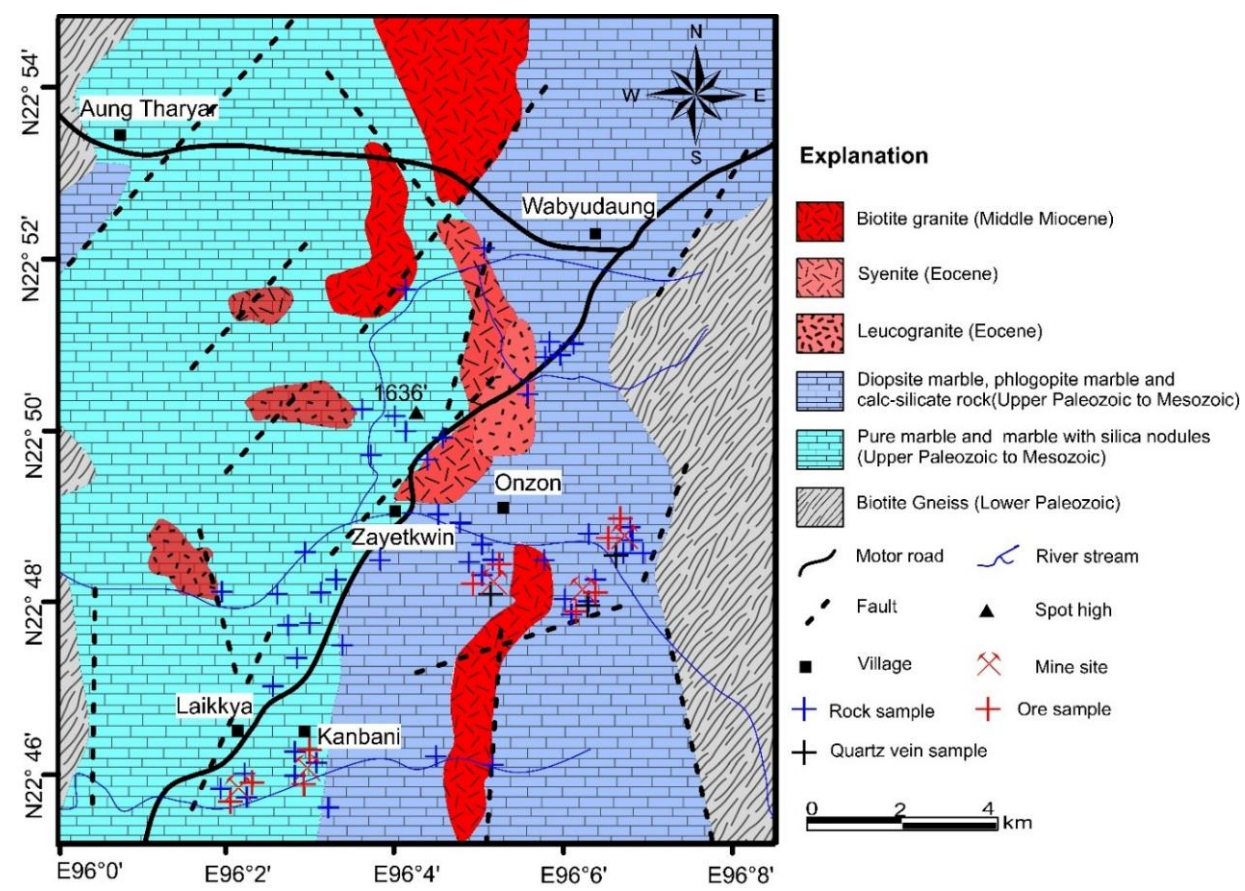

Fig. 2. Simplify geological map of research area with sample location. After Myint Lwin Thein (Thein et al., 1990)

\section{Petrochemistry}

\subsection{Petrochemistry of host rocks}

The major and trace elements composition of host rocks (marble and gneiss) are given in Table- 1 . The chemical characteristics of host rocks are mainly controlled by regional metamorphismas well ashydrothermal activities. Basically, host rock marble is rich in $\mathrm{CaO}$ and $\mathrm{MgO}$ whereas thenotable amount of $\mathrm{Al}_{2} \mathrm{O}_{3}$ content showed that their mica content in marble. Alternatively, gneiss samples are a high content of $\mathrm{SiO}_{2}$ range from 45.983 to 49.672 wt $\%$ where $\mathrm{CaO}$ is not too much between 9.254 to $11.301 w t . \%$ In order to evaluate the compositional change which accompanies deformation and hydrothermal alteration, the concentrations of elements of interest are compared to those of immobile such as Zrrconium. Typically, $\mathrm{Zr}$ is used as animmobile and incompatible element during hydrothermal alteration due to thevery high ionic radius where $\mathrm{SiO}_{2}$ and some of themajor oxide elements cannot use because of alteration effect. In the case of chemically incompatible element $\mathrm{Zr}$ versus compatible elements $(\mathrm{Zn}$ and $\mathrm{Cr}$ ) regression lines which are considered to be mobile with each other in the marble and gneiss units during alteration and deformation. The compatible elements ( $\mathrm{Zn}$ and $\mathrm{Cr}$ ) are more mobile relative to $Z r$ (incompatible) during deformation and hydrothermal alteration as shown by their poor correlations in Figure (Fig. 3). But in thecorrelation between both of incompatible elements, $\mathrm{Zr}$ vs ( $\mathrm{Sr}$ and $\mathrm{Ba}$ ) are considered to be immobile with each other in the marbles and gneiss unit while impacting alteration and deformation. The interelement correlation among the trace elements is significant which is consistent with their similar geochemical behavior. 


\subsection{Petrochemistry of intrusive igneous rocks}

The chemical composition of plutonic igneous rocks at Onzon-Kanbani area was observed to identify the type of igneous rocks and their tectonic setting. The care during sampling was on fresh rocks, it intended to avoid metasomatic changes during hydrothermal alteration. Results of major and trace elements of plutonic igneous rocks from Onzon-Kabani area are summarized in Table- 2 . Major element data and converted normative data (CIPW Norm) of plutonic rocks are used to plot on total alkalis-silica (TAS) diagram as well as albiteanorthite-orthoclase triangular diagram to classify these plutonic rocks. According to total alkalis-silica (TAS) discrimination diagram, the plutonic rocks of study area belong to acidic to intermediate rocks of granite and syenite (Fig. 4). The Ab-An-Or discrimination diagram is intended to avoid the criticism that wt.\%oxide data do not faithfully and to confirm plutonic rock classification. This triangular diagram also showed that plutonic rocks of research area are granite, syenite, and tonalite (Fig. 4) respectively. All of these samples are pointed out as calc-alkaline type by AFM diagram (Fig. 4). Moreover, ACFdiagram also showed that most plutonic rocks of Onzon-Kabani area are 'S-type' peraluminous except two samples of biotite granite which fall in 'I-type' metaluminous.

$\mathrm{Y}$ versus $\mathrm{Nb}$ and $\mathrm{Rb}$ versus $\mathrm{Y}+\mathrm{Nb}$ diagrams (Pearce et al., 1984)were used to discriminate the tectonic environment of plutonic rocks in OnzonKanbani area. These diagrams showed that most of plutonic rocks are in syn-collisional granite (synCOLG) and within plate granite (WPG) except some samples which are placed in volcanic arc granite (VGA) (Fig. 5).

Table 1. Major and trace element composition of least-altered host rocks 'Marble and Gneiss' from Onzon-Kanbani area

\begin{tabular}{|c|c|c|c|c|c|c|c|c|c|c|c|}
\hline $\begin{array}{l}\text { Sample } \\
\text { ID }\end{array}$ & $\begin{array}{l}\text { ZYK1 } \\
\text { (MB) }\end{array}$ & $\begin{array}{l}\text { ZYK2 } \\
\text { (MB) }\end{array}$ & $\begin{array}{l}\text { ZYK3 } \\
\text { (MB) }\end{array}$ & $\begin{array}{c}\text { GS } \\
(\mathrm{MB})\end{array}$ & $\begin{array}{l}\text { GS-8 } \\
(\mathrm{MB})\end{array}$ & $\begin{array}{c}\text { GK } \\
\text { (MB) }\end{array}$ & $\begin{array}{l}\text { TMA6 } \\
\text { (MB) }\end{array}$ & $\begin{array}{c}\text { SZYK3 } \\
\text { (MB) }\end{array}$ & $\begin{array}{l}\text { GY-1 } \\
(\mathrm{GN})\end{array}$ & $\begin{array}{l}\text { GY-9 } \\
\text { (GN) }\end{array}$ & $\begin{array}{c}\text { ZYK15 } \\
\text { (GN) }\end{array}$ \\
\hline $\mathrm{SiO}_{2}(\%)$ & 2.321 & 8.123 & 6.916 & 5.735 & 2.259 & 8.731 & $\begin{array}{r}10.27 \\
9\end{array}$ & 7.786 & $\begin{array}{r}45.98 \\
3\end{array}$ & $\begin{array}{r}49.67 \\
2\end{array}$ & 46.304 \\
\hline $\mathrm{TiO}_{2}$ & 0.007 & 0.166 & 0.132 & 0.182 & 0.009 & 0.117 & 0.102 & 0.194 & 1.249 & 1.482 & 1.385 \\
\hline $\mathrm{Al}_{2} \mathrm{O}_{3}$ & 0.41 & 1.912 & 1.856 & 1.888 & 0.36 & 1.826 & 1.933 & 2.449 & $\begin{array}{r}16.73 \\
9\end{array}$ & $\begin{array}{r}15.37 \\
3\end{array}$ & 16.274 \\
\hline $\mathrm{FeO}$ & 0.615 & 0.697 & 1.035 & 0.772 & 0.607 & 0.546 & 1.183 & 0.727 & 7.356 & 8.882 & 8.238 \\
\hline $\mathrm{MnO}$ & 0.029 & 0.031 & 0.033 & 0.035 & 0.037 & 0.023 & 0.102 & 0.03 & 0.136 & 0.199 & 0.173 \\
\hline $\mathrm{MgO}$ & 6.222 & 1.982 & 1.881 & 1.996 & 6.626 & 1.489 & 2.222 & 1.765 & 6.416 & 7.676 & 7.029 \\
\hline $\mathrm{CaO}$ & $\begin{array}{r}48.32 \\
6\end{array}$ & $\begin{array}{r}54.13 \\
4\end{array}$ & $\begin{array}{r}52.18 \\
6\end{array}$ & $\begin{array}{r}52.19 \\
9\end{array}$ & $\begin{array}{r}46.12 \\
4\end{array}$ & $\begin{array}{r}50.52 \\
7\end{array}$ & $\begin{array}{r}48.52 \\
7\end{array}$ & 50.583 & $\begin{array}{r}11.30 \\
1\end{array}$ & 9.254 & 11.088 \\
\hline $\mathrm{Na}_{2} \mathrm{O}$ & 0.291 & 0.005 & 0.045 & 0.006 & 0.383 & 0.015 & 0.003 & 0.063 & 1.411 & 1.726 & 1.669 \\
\hline $\mathrm{K}_{2} \mathrm{O}$ & 0.378 & 0.801 & 0.59 & 0.58 & 0.019 & 0.861 & 0.358 & 0.9 & 2.317 & 2.798 & 2.25 \\
\hline $\mathrm{P}_{2} \mathrm{O}_{5}$ & 0.003 & 0.012 & 0.01 & 0.011 & 0.001 & 0.013 & 0.006 & 0.012 & 0.738 & 0.224 & 0.833 \\
\hline LOI & 40.01 & 31.18 & 34.73 & 36.42 & 43.5 & 35.69 & 35.12 & 35.37 & 3.82 & 2.13 & 2.68 \\
\hline Total & $\begin{array}{r}98.61 \\
2\end{array}$ & $\begin{array}{r}99.04 \\
3\end{array}$ & $\begin{array}{r}99.41 \\
4\end{array}$ & $\begin{array}{r}99.82 \\
4\end{array}$ & $\begin{array}{r}99.92 \\
5\end{array}$ & $\begin{array}{r}99.83 \\
8\end{array}$ & $\begin{array}{r}99.83 \\
5\end{array}$ & 99.879 & $\begin{array}{r}97.46 \\
6\end{array}$ & $\begin{array}{r}99.41 \\
6\end{array}$ & 97.923 \\
\hline $\mathrm{V}(\mathrm{ppm})$ & 5 & 9 & 13 & 22 & 3 & 12 & 15 & 13 & 298 & 334 & 329 \\
\hline $\mathrm{Cr}$ & 36 & 41 & 39 & 45 & 38 & 42 & 33 & 38 & 42 & 140 & 55 \\
\hline Co & 11 & 18 & 22 & 24 & 10 & 21 & 23 & 16 & 32 & 33 & 35 \\
\hline $\mathrm{Ni}$ & 21 & 25 & 24 & 27 & 19 & 22 & 26 & 28 & 48 & 74 & 51 \\
\hline $\mathrm{Cu}$ & 6 & 8 & 9 & 11 & 5 & 9 & 15 & 7 & 50 & 25 & 47 \\
\hline $\mathrm{Zn}$ & 21 & 29 & 31 & 33 & 18 & 39 & 66 & 38 & 113 & 148 & 124 \\
\hline $\mathrm{Pb}$ & 96 & 5 & 7 & 1 & 112 & n.d & 74 & 7 & 15 & 10 & 1 \\
\hline As & n.d & 7 & 4 & 7 & n.d & 10 & 6 & 5 & 13 & 6 & 16 \\
\hline Mo & 12 & 15 & 14 & 14 & 9 & 17 & 14 & 17 & 48 & 14 & 41 \\
\hline $\mathrm{Sr}$ & 181 & 481 & 477 & 473 & 179 & 473 & 495 & 548 & 3822 & 542 & 3324 \\
\hline $\mathrm{Ba}$ & n.d & 81 & 105 & 84 & n.d & 180 & 24 & 115 & 1692 & 425 & 1532 \\
\hline$Y$ & 6 & 7 & 11 & 9 & 4 & 10 & 6 & 14 & 20 & 48 & 21 \\
\hline $\mathrm{Zr}$ & 1 & 21 & 34 & 17 & n.d & 66 & 26 & 37 & 53 & 68 & 36 \\
\hline $\mathrm{Nb}$ & n.d & 2 & 1 & 1 & n.d & 2 & 1 & 2 & 3 & 13 & 4 \\
\hline $\mathrm{Rb}$ & 4 & 38 & 30 & 29 & 3 & 36 & 18 & 53 & 57 & 182 & 56 \\
\hline
\end{tabular}

Note: Total Fe content expressed as $\mathrm{FeO}_{\text {(toot) }}$ n.d=below detection limit; major element and LOI are weight percent; trace elements are in ppm 

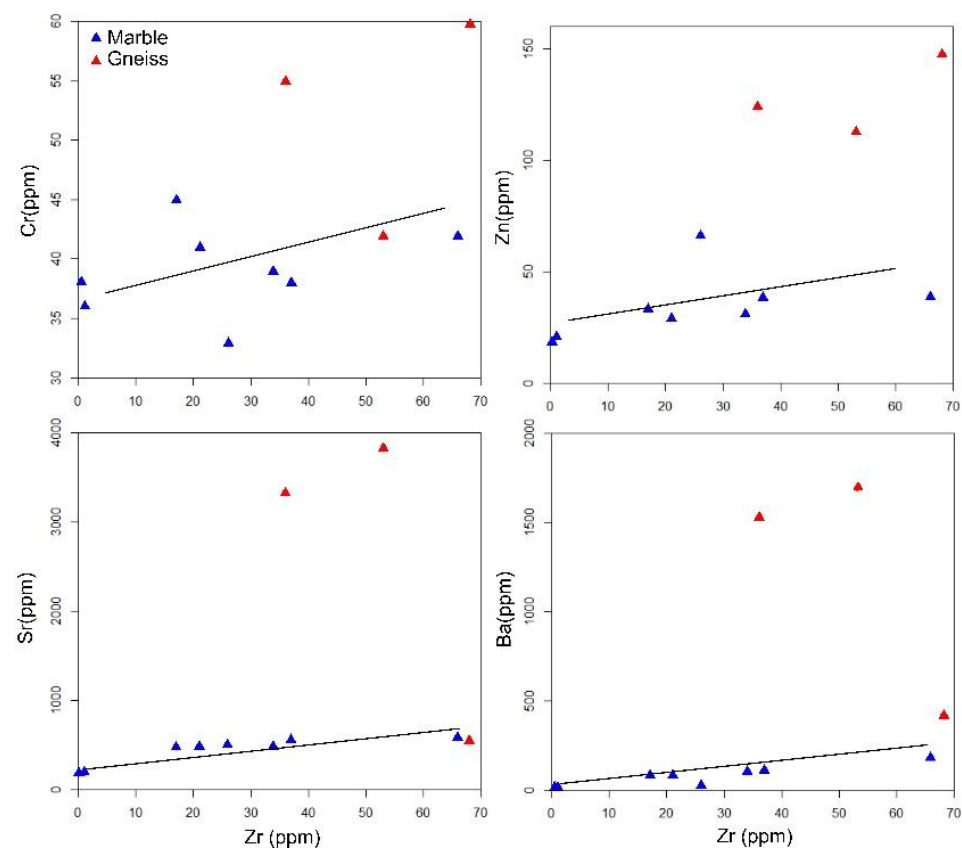

Fig..3 Binary variation diagrams in $\mathrm{Cr}$, Zn, $\mathrm{Sr}$ and $\mathrm{Ba}$ (all in ppm) for host rocks of Onzon-Kabani area whereas $\mathrm{Zn}$ and $\mathrm{Cr}$ are compatible elements, and $\mathrm{Zr}$, Srand Ba are incompatible elements
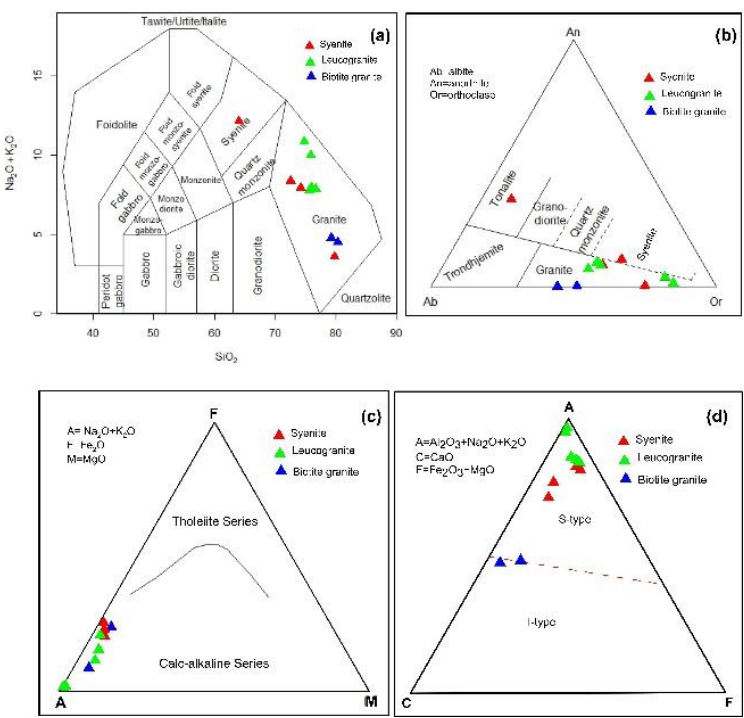

Fig.4. (a) Classification diagrams of plutonic rocks using total alkaline versus $\mathrm{SiO}_{2}$ (Middlemost, 1994), and (b) Ternary plot diagram in normative Ab-An-Or for the plutonic rocks of the study area (O'Connor, 1965), (c) AFM diagram for determining sub-magma type 'tholeiite or calc-alkaline', and (d) ACF diagram determining I-type and S-type granitoid(Hyndman, 1986)
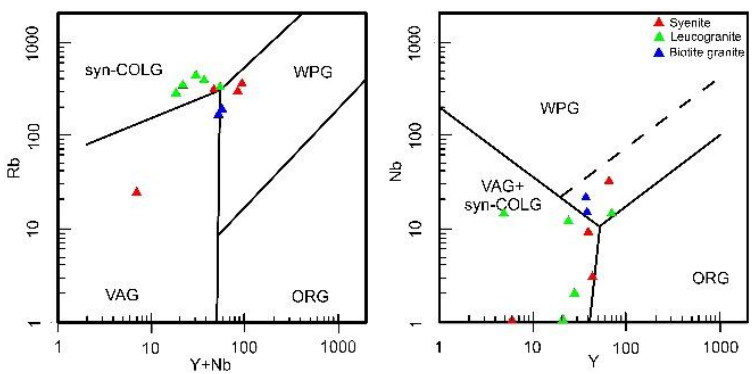

Fig.5. Position of Onzon-Kanbani plutonic sampleson $Y$ versus $\mathrm{Nb}$ and $\mathrm{Rb}$ versus $\mathrm{Y}+\mathrm{Nb}$ diagram(Pearce et al., 1984). Abbreviations: ORG $=$ oceanic ridge granite,
VAG $=$ volcanic granite, WPG $=$ within plate granite and synCOLG=syn-collision granite

\section{Mineralization and associated hydrothermal alterations}

Gold and base metal mineralization hosted by marble is closely associated with intense hydrothermal alteration. Generally, mineralization is controlled by NE-SW trending faults within fracture and shear zones. Open space fracture filling veins are common characteristicswith minor disseminated mineralization in marble. Many kinds of vein textures are observed in mineral ization vein such as massive vein, crustiform, banded, lattice, bladed carbonate, comb, and cockade. Some of the texturesare diagnostic textures of boiling (lattice, bladed, banded, crustiform). They are indicated to boiling fluids of near neutral to alkaline $\mathrm{pH}$ condition (Gregg and Jaireth, 1995; Simmons and Christenson, 1994) (Fig. 7). Many local worksites are working on the narrow mineralization zones where the width of veins are generally 0.5 to 5 meters.

Wall rock alterations related with hydrothermal fluid are observed in Onzon-Kanbani area but not wide area scale. Mostly, hydrothermal alteration hal os are developed around mineral ization veins as narrow zones. Basically, hydrothermal alteration is overlapped to regional metamorphism. Microscopic observation and X-ray diffraction patterns are used to identify the type of alterations which happen by hydrothermal impact. There are three distinct hydrothermal alteration zones from proximal to distal of hydrothermal conduct.

Silicic alteration zone or inner core of alteration halos, it is mainly composed of quartz, calcite, adularia and minor amount of illite and chlorite (Fig.6). Generally, this alteration is overlapped with mineralization vein but groundmass is strongly 
silicified. Gold and base metal mineralization are observed in massive and banded quartz veins. Hydrothermal breccia is also frequently observed near this alteration zone. These breccia are characterized by a milled matrix of pyrite. Some of the sulphides are oxidized because of deep weathering.

Sericite-illite alteration is observed as narrow zone next to silicic alteration zone. But this zone is not well developed in some alteration halos. The main constituents of minerals from this altered zone are sericite, illite, quartz, calcite and a minor amount of pyrite. Sericite occurs as fine grained and spread out like dusty (Fig. 6).

Propylitic alteration is an outer most zone of alteration and wild area coverage. This zone is characterized by the presence of chlorite, epidote,actinolite, smectite, and illite, (Fig. 6). It is still preserve the primary texture of the original rock. It is believed that some part of propylitic alteration is not related to ore forming hydrothermal system (Evans, 1987), overlapped to regional metamorphism. Most of hydrothermal minerals from each altered zones showed that near neutral condition of $\mathrm{pH}$ (e.g. adularia, calcite, illite, sericite and chlorite).
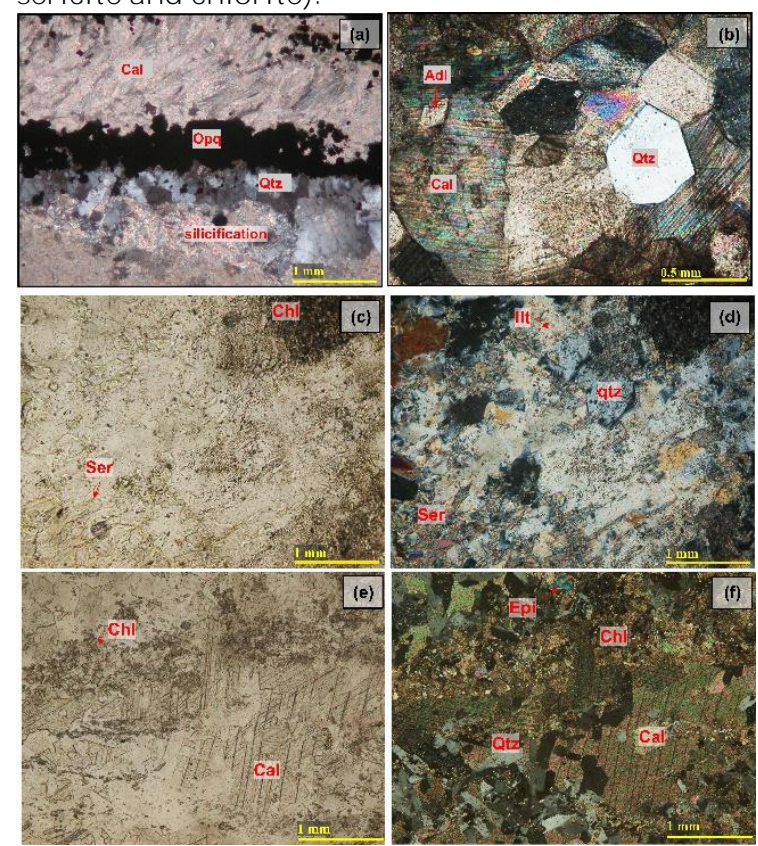

Fig. 6. Photomicrographs of (a \& b) Silicic alteration, (c \& d) Sericite-illite alteration zone, (e \& f) Propylitic alteration zone. Abbreviations: calcite (Cal), quartz (Qtz), adularia (Adl), sericite (Ser), illite (IIt), epidote (Epi), chlorite (Chl) and opaque mineral (Opq).

\section{Geochemistry of altered rocks}

The major and trace elements concentration of the altered rocks are varied depend on alteration intensity as well as the presence of a chemical ion exchange between wall rocks and hydrothermal fluids. The altered zonation reflects changes in the fluid composition with time and interaction of hydrothermal fluid and wall rocks (Meyer and Hemley, 1967).

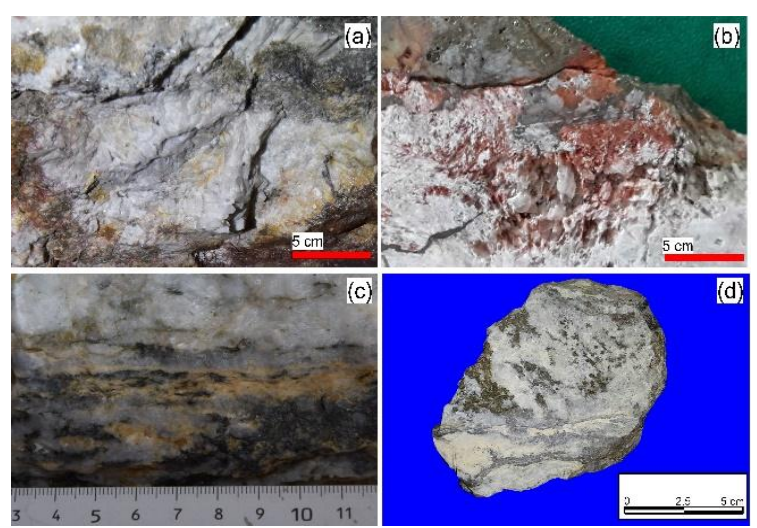

Fig. 7. Some of themineralization vein textures (a) Lattice texture, (b) bladed calcite, (c) banded vein texture and (d) crustiform texture

In Onzon-Kabani area,alteration zones are basicallyhosted in marble unit as narrow zonation. The major and trace elements of the least-altered rocks and altered rocks of each zones are shown in Table 1 and 3 . In this case each of the alteration zones has measured enrichment and depletion of major and trace elements relative to the leastaltered rock (Fig. 8).The petrochemistry of zone 1 showed that silicic altered rocks are enriched in $\mathrm{SiO}_{2}, \mathrm{Al}_{2} \mathrm{O}_{3}, \mathrm{~K}_{2} \mathrm{O}$, and $\mathrm{S}$ indicating occurrences of abundant quartz, aluminium-bearing clay (illite), \pm adularia and sulphides whereas any other elements such as $\mathrm{FeO}, \mathrm{MgO}, \mathrm{M} \mathrm{nO}$ and $\mathrm{CaO}$ are depleted. But in zone 2 of sericite-illite alteration zone, $\mathrm{SiO}_{2}$ is quite reduced compared with silicic alteration zone. Instead of $\mathrm{SiO}_{2}$, CaO is increased in remarkable amountbut still lowrelatively to least-altered rocks.Moreover, $\mathrm{Al}_{2} \mathrm{O}_{3}, \mathrm{~K}_{2} \mathrm{O}$, $\mathrm{FeO}$ and $\mathrm{MgO}$ are also high because of abundant illite (sericite) and chlorite. Samples from zone 3 'propylitic alteration zone', $\mathrm{CaO}$ shows high amount near least-altered rocks whereas $\mathrm{Al}_{2} \mathrm{O}_{3}$ and $\mathrm{K}_{2} \mathrm{O}$ are depleted. Locally enrichments of $\mathrm{MgO}, \mathrm{Al}_{2} \mathrm{O}_{3}$ and $\mathrm{FeO}$ are indicated that the development of chloritization in propylitic alteration. The wt.\%of loss of ignition (LOI) increase significantly to least altered samples (marbles). This is due to dissociation of $\mathrm{CaCO}_{3}$ and dolomite CaMg $\left(\mathrm{CO}_{3}\right)_{2}$ that partially transform themselves into carbon dioxide gas at temperatures higher than $750^{\circ} \mathrm{C}$. Generally, high field strength elements of Al, $\mathrm{Ti}$, and $\mathrm{Zr}$ were assumed to be immobile elements during the alteration and deformation process. When plotting these minerals from least-altered and altered rocks in $\mathrm{TiO}_{2}$ vs $\mathrm{Zr}$ and $\mathrm{TiO}_{2}$ vs $\mathrm{Al}_{2} \mathrm{O}_{3}$ binary/bivariate diagrams, a general single trend of alteration is observed in both of diagrams but some of silicic and sericite-illite alteration samples are a little bit deficient from these lines (Fig.9 ).It mean hydrothermal alteration of silicic and sericite-illite alteration is quite high intensity. 

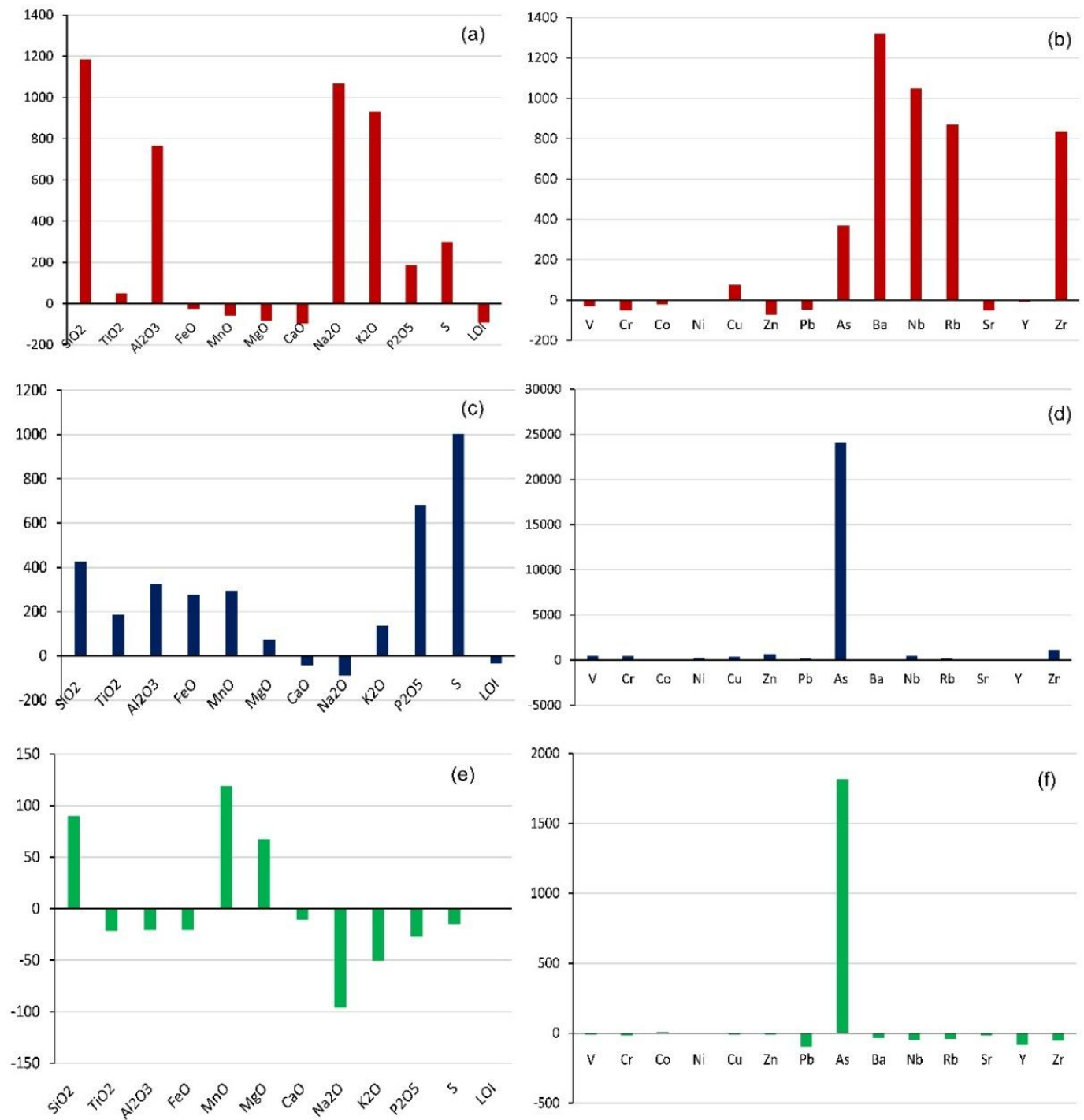

Fig.8 Enrichment -depletion diagram showing major oxides ( $w \mathrm{t} \% \mathrm{q}$ and trace element (ppm) during alteration in different zones of hydrothermal alteration of Onzon-Kanbani area based on mean data of least-altered samples as a reference for calculations, (a) and (b) for silicic alteration zone, (c) and (d) for sericite-illite alteration zone, and (e) and (f) for propylitic alteration zone
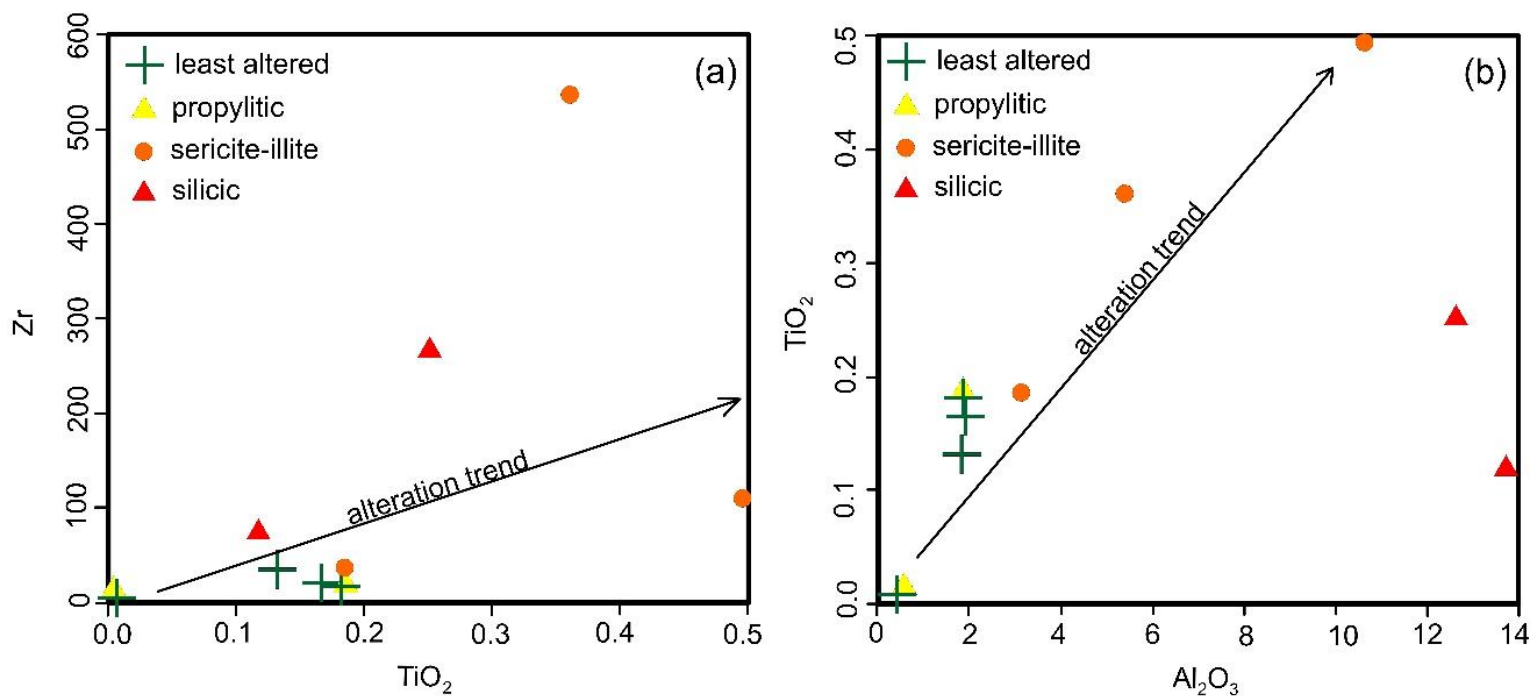

Fig.9 Binary diagrams $\mathrm{Zr}-\mathrm{TiO}_{2}$ and $\mathrm{TiO}_{2}-\mathrm{Al}_{2} \mathrm{O}_{3}$ showing plot of the least-altered and altered rocks with alteration trend 
Table 2. Major and trace element composition of plutonic rocks from Onzon-Kanbani area

\begin{tabular}{|c|c|c|c|c|c|c|c|c|c|c|c|}
\hline $\begin{array}{l}\text { Sample } \\
\text { ID }\end{array}$ & $\begin{array}{r}\text { ZYKI-2 } \\
\text { (luc) }\end{array}$ & $\begin{array}{r}\text { ZYKI-3 } \\
\text { (luc) }\end{array}$ & $\begin{array}{r}\text { ZYK-5 } \\
\text { (luc) }\end{array}$ & $\begin{array}{r}\text { ZYK-9 } \\
\text { (syn) }\end{array}$ & $\begin{array}{r}\text { ZYK- } \\
11 \\
\text { (syn) }\end{array}$ & $\begin{array}{r}\text { ZYK- } \\
12 \\
(\mathrm{Gr})\end{array}$ & $\begin{array}{r}\text { ZYK- } \\
18 \\
\text { (luc) }\end{array}$ & $\mathrm{KB}(\mathrm{Gr})$ & $\begin{array}{r}\text { ZYKS-1 } \\
\text { (luc) }\end{array}$ & $\begin{array}{r}\text { ZYKS-2 } \\
\text { (syn) }\end{array}$ & $\begin{array}{r}\text { ZYKS-3 } \\
\text { (luc) }\end{array}$ \\
\hline $\mathrm{SiO}_{2}(\%)$ & 74.27 & 75.4 & 75.49 & 78.85 & 73.73 & 79.77 & 61.51 & 79.07 & 75.63 & 75.51 & 71.53 \\
\hline $\mathrm{TiO}_{2}$ & 0.03 & 0.27 & 0.03 & 0.07 & 0.38 & 0.26 & 0.2 & 0.01 & 0.05 & 0.34 & 0.33 \\
\hline $\mathrm{Al} 2 \mathrm{O} 3$ & 13.65 & 12.48 & 13.09 & 11.85 & 12.69 & 5.09 & 13.02 & 5.34 & 12.38 & 12.08 & 13.91 \\
\hline $\mathrm{FeO}$ & 0.23 & 2.43 & 0.21 & 1.21 & 3.1 & 1.73 & 1.8 & 0.55 & 1.77 & 1.18 & 2.56 \\
\hline $\mathrm{MnO}$ & 0.01 & 0.03 & 0.02 & 0.01 & 0.07 & 0.05 & 0.03 & 0.01 & 0.01 & 0.03 & 0.06 \\
\hline $\mathrm{MgO}$ & 0.02 & 0.32 & 0.05 & 0.16 & 0.16 & 0.29 & 0.81 & 0.28 & 0.47 & 0.53 & 0.47 \\
\hline $\mathrm{CaO}$ & 0.28 & 0.89 & 0.57 & 3.13 & 1.17 & 7.52 & 6.88 & 9.57 & 1.08 & 1.26 & 1.42 \\
\hline $\mathrm{Na} 2 \mathrm{O}$ & 1.14 & 2.78 & 1.2 & 2.76 & 2.44 & 1.15 & 2.82 & 2.65 & 2.42 & 2.51 & 1.99 \\
\hline $\mathrm{K} 2 \mathrm{O}$ & 9.68 & 5.03 & 8.78 & 0.78 & 5.51 & 2.35 & 8.86 & 2.12 & 5.48 & 5.25 & 6.32 \\
\hline P2O5 & 0.02 & 0.02 & 0.02 & 0.01 & 0.04 & 0.06 & 0.01 & 0.01 & 0.03 & 0.06 & 0.01 \\
\hline LOI & 0.5 & 0.22 & 0.31 & 0.63 & 0.48 & 0.51 & 3.3 & 0.32 & 0.61 & 1.2 & 1.12 \\
\hline Total & 99.83 & 99.87 & 99.77 & 99.46 & 99.79 & 99.78 & 99.24 & 99.93 & 99.23 & 99.15 & 99.72 \\
\hline $\mathrm{V}(\mathrm{ppm})$ & 6 & 6 & 5 & 2 & 18 & 14 & 15 & 7 & 21 & 2 & 8 \\
\hline $\mathrm{Cr}$ & 22 & 24 & 24 & 27 & 20 & 30 & 22 & 20 & 19 & 24 & 23 \\
\hline Co & 21 & 9 & 10 & 13 & 2 & 7 & 12 & 4 & 2 & 17 & 4 \\
\hline $\mathrm{Ni}$ & 27 & 26 & 25 & 21 & 28 & 26 & 23 & 24 & 24 & 21 & 23 \\
\hline $\mathrm{Cu}$ & 3 & 4 & 7 & 8 & 9 & 6 & 50 & 7 & 5 & 7 & 8 \\
\hline $\mathrm{Zn}$ & 8 & 103 & 4 & 20 & 93 & 51 & 12 & 65 & 63 & 46 & 62 \\
\hline $\mathrm{Pb}$ & 20 & 27 & 35 & 11 & 25 & 25 & 43 & 28 & 35 & 25 & 21 \\
\hline As & 5 & 8 & 8 & 6 & 10 & 6 & 10 & 9 & 8 & 5 & 9 \\
\hline Mo & 12 & 25 & 33 & 14 & 27 & 17 & 16 & 16 & 12 & 18 & 15 \\
\hline $\mathrm{Rb}$ & 437 & 296 & 336 & 27 & 291 & 165 & 359 & 187 & 281 & 378 & 308 \\
\hline $\mathrm{Sr}$ & 276 & 35 & 263 & 33 & 56 & 266 & 560 & 267 & 225 & 617 & 596 \\
\hline $\mathrm{Ba}$ & 644 & 211 & 660 & 11 & 214 & 1033 & 4552 & 1015 & 484 & 1246 & 1568 \\
\hline$Y$ & 29 & 72 & 21 & 6 & 41 & 39 & 66 & 37 & 5 & 25 & 45 \\
\hline$Z r$ & n.d & 473 & 429 & 37 & 731 & 249 & 17 & 14 & 122 & 425 & 476 \\
\hline $\mathrm{Nb}$ & 2 & 14 & 1 & 1 & 9 & 15 & 32 & 22 & 14 & 12 & 3 \\
\hline
\end{tabular}

Note: Total Fe content expressed as $\mathrm{FeO}_{\text {(tot) }}$; $\mathrm{n} . \mathrm{d}=$ =below detection limit; major element and LOI are weight percent; trace elements are in ppm

Table 3. Result of XRF and ICP-OES altered host rock from Onzon-Kanbani area, Thabeikkyin Township, Mandalay region,

\begin{tabular}{lrrrrrrrr}
\hline \multicolumn{1}{c}{ Silicic Alteration } & \multicolumn{2}{c}{ Sericite alteration } & \multicolumn{2}{c}{ Propylitic } & least-altered \\
\hline & GM-8 & GM-9 & GK-3 & GK-5 & CHL1 & GS1 & GM11 & mean $(\mathrm{n}=4)$ \\
\hline SiO2 (\% & 72.507 & 75.66 & 38.975 & 12.556 & 39.396 & 5.735 & 16.169 & 5.7737 \\
\hline TiO2 & 0.25 & 0.117 & 0.497 & 0.184 & 0.36 & 0.182 & 0.009 & 0.1217 \\
\hline Al2O3 & 12.582 & 13.649 & 10.708 & 3.127 & 5.428 & 1.888 & 0.51 & 1.5165 \\
\hline FeO & 0.796 & 0.347 & 5.789 & 1.003 & 2.03 & 0.772 & 0.469 & 0.7797 \\
\hline MnO & 0.027 & 0.001 & 0.202 & 0.129 & 0.049 & 0.035 & 0.105 & 0.032 \\
\hline MgO & 0.697 & 0.212 & 3.242 & 0.994 & 11.675 & 1.996 & 8.134 & 3.0202 \\
\hline CaO & 2.269 & 0.703 & 18.791 & 45.956 & 22.449 & 52.199 & 39.786 & 51.7112 \\
\hline Na2O & 0.137 & 1.889 & 0.022 & 0.001 & 0.005 & 0.006 & 0.001 & 0.0867 \\
\hline K2O & 6.521 & 5.587 & 3.033 & 0.609 & 0.542 & 0.58 & 0.003 & 0.5872 \\
\hline P2O5 & 0.032 & 0.02 & 0.09 & 0.022 & 0.099 & 0.011 & 0.002 & 0.009 \\
\hline S & 0.4396 & 0.0127 & 1.8 & 0.0318 & 0.0377 & 0.0851 & 0.0108 & 0.0564 \\
\hline LOI & 3.55 & 1.62 & 16.06 & 35.31 & 17.82 & 36.42 & 34.76 & 35.585 \\
\hline
\end{tabular}




\begin{tabular}{lrrrrrrrr}
\hline Total & 99.8076 & 99.8177 & 99.209 & 99.9228 & 99.8907 & 99.9091 & 99.9588 & 99.2232 \\
\hline $\mathrm{V}(\mathrm{ppm})$ & 11 & 6 & 163 & 17 & 32 & 22 & n.d & 12.25 \\
\hline $\mathrm{Cr}$ & 18 & 19 & 554 & 34 & 46 & 45 & 24 & 40.25 \\
\hline $\mathrm{Co}$ & 8 & 22 & 20 & $\mathrm{n} . \mathrm{d}$ & 15 & 24 & 16 & 18.75 \\
\hline $\mathrm{Ni}$ & 24 & 24 & 194 & 24 & 27 & 27 & 19 & 24.25 \\
\hline $\mathrm{Cu}$ & 18 & 12 & 92 & 10 & 9 & 11 & 4 & 8.5 \\
\hline $\mathrm{Zn}$ & 88 & 71 & 535 & 68 & 67 & 33 & 18 & 28.5 \\
\hline $\mathrm{Pb}$ & 89 & 60 & 210 & 14 & 4 & 1 & n.d & 27.25 \\
\hline $\mathrm{As}$ & 39.33 & 2.92 & 3267.87 & $\mathrm{n} . \mathrm{d}$ & $\mathrm{n} . \mathrm{d}$ & 172.26 & $\mathrm{n} . \mathrm{d}$ & 4.5 \\
\hline $\mathrm{Ba}$ & 866 & 1051 & 224 & 49 & 104 & 84 & 5 & 67.5 \\
\hline $\mathrm{Nb}$ & 14 & 9 & 4 & 6 & 8 & 1 & n.d & 1 \\
\hline $\mathrm{Rb}$ & 289 & 201 & 120 & 43 & 30 & 29 & 2 & 25.25 \\
\hline $\mathrm{Sr}$ & 124 & 248 & 317 & 367 & 199 & 473 & 199 & 403 \\
\hline $\mathrm{Y}$ & 9.32 & 5.81 & 17.67 & 6.43 & 8.42 & n.d & 2.78 & 8.25 \\
\hline $\mathrm{Zr}$ & 267 & 75 & 111 & 32 & 537 & 17 & n.d & 18.25 \\
\hline
\end{tabular}
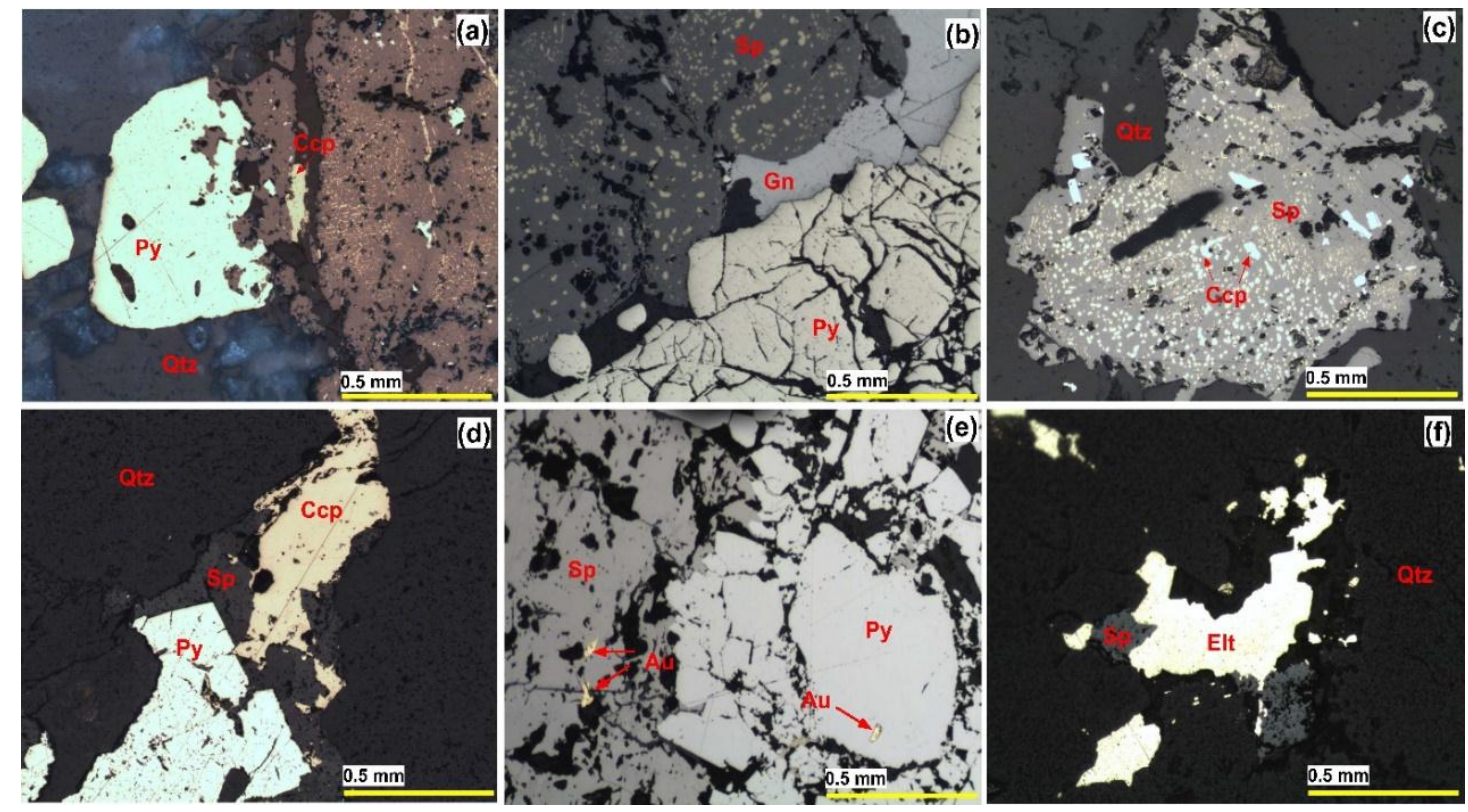

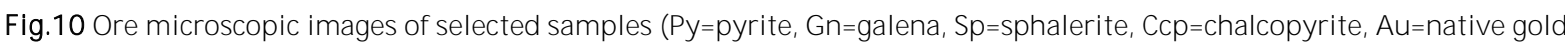
and Elt=electrum)

\section{Ore mineralogy and paragenetic sequence}

Mineralogically, gold occurs as free grains or locked within pyrite, sphalerite, galena and gangue mineral quartz. There are two types of gold, 'native gold' and 'electrum' based on their atomic percent of Au. Electrum ( $<80$ at $\%$ is mostly observed as large grained in gold bearing quartz vein but native gold ( $>80$ at $\%$ is observed as fine grained in base metal quartz-carbonate vein and carbonate base metal sulphides vein (Fig.11). Other common ore minerals in research area are pyrite, marcasite, chalcopyrite, sphalerite, galena, arsenopyrite, chalcocite, covellite, hematite, and goethite. Pyrite, galena, sphalerite, chalcopyrite, marcasite, and arsenopyrite are primary ore minerals whereas chal cocite, covellite, hematite, and goethite occur as late minerals, their occurrences reflect the oxidation of primary sulphides such as pyrite and chalcopyrite by circulation of surficial water. Pyrite is the most abundant sulphide mineral in the ore body. It occurs over the entire period of mineralization as fine-grained massive aggregates to large euhedral grains.

According to thevein and mineral structures and textures, there are three main paragenetic stages; 1) mineralization stage, 2) barren stage and 3) oxidation stage (Table-4). In mineralization stage, the early formed quartz, pyrite, and minor calcite minerals are observed away from late phase 
sulphides and quartz core vein. And also early formed pyrite and quartz minerals showed their euhedral crystal forms whereas anhedral sphalerite is younger than quartz and pyrite in order of deposition. Some of theanhedral sphalerites are replaced along the boundary by later formed galena. Moreover, disseminated chalcopyrite rods and small grainsoccur in sphalerite as exsolution texture (Fig. 10). Gold is mostly observed in quartz gangue, pyrite, sphalerite, galena and chalcopyrite ground mass as disseminated specks (Fig. 10). Actually, quartz, calcite, and pyrite are observed the entire period of mineralization as more or less amount. Sericite and aminor amount of adularia are also found together with quartz at mineralization vein. After mineralization stage, veins are barren like a calcite or quartz vein with very minor amount of pyrite. Subsequently, oxidation stage is going on by circulated meteoric water whereas hematite, goethite,and chalcocite are formed from primary sulphides.

Table 4. Generlized paragenetic sequence of OnzonKanbani area

\begin{tabular}{|c|c|c|c|c|}
\hline \multirow{2}{*}{ Minerals } & \multicolumn{2}{|c|}{ Stage-1 (Mineralization) } & \multirow{2}{*}{$\begin{array}{l}\text { Stage-2 } \\
\text { (Barren) }\end{array}$} & \multirow{2}{*}{$\begin{array}{c}\text { Oxidation } \\
\text { stage }\end{array}$} \\
\hline & Phase-1 & Phase-2 & & \\
\hline \\
\hline \multicolumn{5}{|l|}{$\begin{array}{l}\text { Adularia } \\
\text { Sericite }\end{array}$} \\
\hline \multirow{2}{*}{\multicolumn{5}{|c|}{$\begin{array}{l}\text { Sericite } \\
\text { Calcite }\end{array}$}} \\
\hline \multirow{2}{*}{\multicolumn{5}{|c|}{ Illite }} \\
\hline & & & & \\
\hline \multicolumn{5}{|l|}{ Pyritc } \\
\hline \multirow{2}{*}{\multicolumn{5}{|c|}{ Sphalcritc }} \\
\hline & & & & \\
\hline \multicolumn{5}{|l|}{ Chalcopyrite } \\
\hline \multicolumn{5}{|l|}{ Electrum } \\
\hline \multirow{2}{*}{\multicolumn{5}{|c|}{$\begin{array}{l}\text { Native Gold } \\
\text { Marcasitc }\end{array}$}} \\
\hline \multirow{2}{*}{\multicolumn{5}{|c|}{$\begin{array}{l}\text { Marcasttc } \\
\text { Chalcocite }\end{array}$}} \\
\hline \multirow{2}{*}{\multicolumn{5}{|c|}{ Covellite }} \\
\hline & & & & \\
\hline $\begin{array}{l}\text { Hematile } \\
\text { Goethite }\end{array}$ & & & & \\
\hline
\end{tabular}

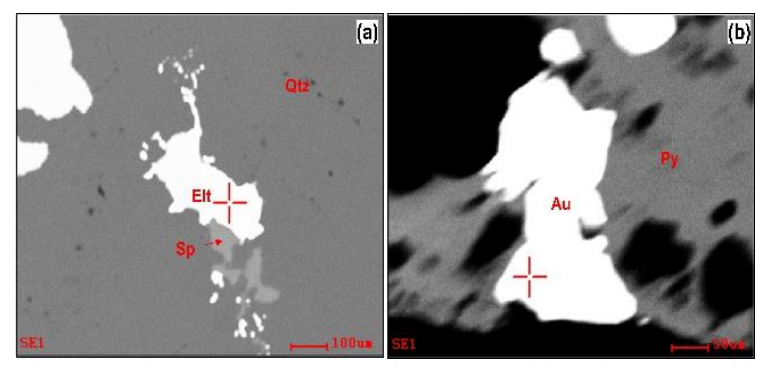

Fig.11 Back scatter image of electrum gold and native gold in mineralization vein (Elt=electrum, $A u=$ native gold, $\mathrm{Sp}=$ sphalerite, $\mathrm{Py}=$ pyrite, $\mathrm{Qtz}=$ quartz)

\section{Fluid inclusion study}

Double polished quartz wafers were prepared for fluid inclusion study. From petrographic study, two-phase (liquid, vapor) fluid inclusions are dominant type of primary fluid inclusion. They are observed as two-phase liquid rich, two-phase coexisting of liquid-rich and vapor-rich and two phase vapor-rich fluid inclusions. Moreover, microthermometry was carried out for primary fluid inclusions in quartz from gold and base metal mineralization veins. Homogenization temperature Th of fluid inclusion showed range from $159^{\circ} \mathrm{C}$ to $315^{\circ} \mathrm{C}$ where the boiling temperature was estimated to be $170^{\circ} \mathrm{C}$. The histogram of homogenization temperature is shown in figure (Fig. 12). Salinities of the fluid inclusions were calculated by Bodnar's equation using ice meting temperature $\mathrm{Tm}$ (Bodnar, 1993). The salinity range is low to moderate 0.88 to 12.51 wt\% $\mathrm{NaCl}$ equivalent. The plot diagram of homogenization temperature and salinity are showed negative trend (Fig. 13).

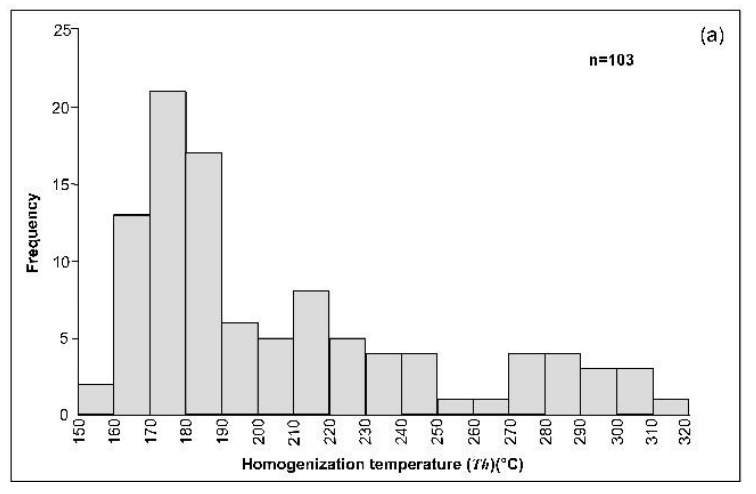

Fig.12 Homogenization temperatures of fluid inclusion in quartz from gold and base metal mineralization vein

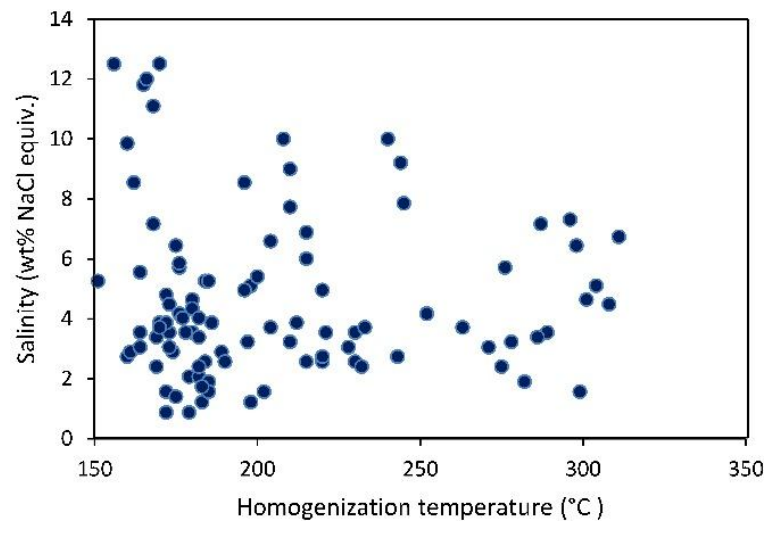

Fig. 13. Binary plot diagram ofsalinity vs. homogenization temperature Th of fluid inclusions

\section{Discussion and conclusion}

Gold mineralization in Onzon-Kanbani area ishosted in metamorphic rocks. The older metamorphic rocks are intruded by younger plutonic rocks. Mineralization is commonly observed as fracture filling vein and disseminated nature hosted in marble unit. Petrochemistry of host rocks is mainly controlled by regional metamorphism and hydrothermal activities. Basically, host rocks are rich in $\mathrm{CaO}$ and $\mathrm{MgO}$ whereas the notable amount of $\mathrm{Al}_{2} \mathrm{O}_{3}$ content is showed their mica content in marble.Both of 'I-type' biotite granite and 'S-type' leucogranite and syenite of granitoid rocks are observed as intrusive bodies where most of the rocks are placed in the field of 
syn-collisional granite and within plate granite. Hydrothermal alteration halos are developed as narrow zones beside of hydrothermal conduit or mineralization vein. They are silicic, sericite-illite and propylitic alteration zones from proximal to distal of hydrothermal conduits. Hydrothermal alteration in Onzon-Kanbani area is regard as lowsulphidation epithermal system as indicated by the characteristic of alteration style and alteration mineral assemblages such as quartz, calcite, tadularia, sericite, illite and smectite. These alteration minerals are showed that the temperature decreasing to the outer zone of alteration as well as indicated that the higher $\mathrm{pH}$, near neutral condition of hydrothermal system. Generally, hydrothermal alteration is overlapped to regional metamorphism. The geochemistry of each altered zone reflects changing of fluid composition and interaction of hydrothermal fluid and wall rock. According to immobile elements characteristics of least-altered and altered rocks, alteration intensity is higher to silicic and sericite-illite alteration. $\mathrm{SiO}_{2}$ and $\mathrm{CaO}$ content are inversely proportional in each altered zone. Enrichments of $\mathrm{S}, \mathrm{Pb}, \mathrm{Zn}$, and $\mathrm{Cu}$ from silicic altered zone indicate that fracture filling vein mineralization is more common than disseminated mineralization. In ore mineralogy, hypogene ore mineral such as pyrite, sphalerite, galena, chalcopyrite and minor native gold and electrum are precipitated in mineralization stage. After this veins are barren by deposition of calcite or quartz at the end of mineralization stage. Some of hypogenesulphide minerals are oxidized to supergene minerals during oxidation stage. According to fluid inclusions petrography whereas coexisting of liquid rich and vapor rich fluid inclusions as well as some of vein textures such as bladed, banded and lattice are strongly advocated that fluid boiling, iseffective on such a precipitation of ore minerals. Moreover, homogenization temperature $\left(159^{\circ} \mathrm{C}-315^{\circ} \mathrm{C}\right)$ and salinity $(0.88$ to 12.51 wt. $\% \mathrm{NaCl}$ equiv.) range are acceptable to say it formed in the epithermal environment.

\section{Acknowledgements}

This research is supported by AUN/SEED-Net (JICA program).We would like to thank all of local companies and owners for permission to conduct research work in there and for helping during field investigation and general discussion.

\section{References}

Barley, M.E., Pickard, A.L., Zaw, K., Rak, P., Doyle, M.G., 2003. Jurassic to Miocene magmatism and metamorphism in the Mogok metamorphic belt and the India-Eurasia collision in Myanmar. Tectonics 22, n/a-n/a. doi: 10.1029/2002TC001398

Bender, F., 1983. Geology of Burma, 293 p. Gebrüder Borntraeger, Berlin and Stuttgart.

Bodnar, R.J., 1993. Revised equation and table for determining the freezing point depression of H 57, 683-684.
Evans, A.M., 1987. An Introduction to Ore Geology, 2nd edn. ed. Blackwell, Oxford.

Gregg and Jaireth, S.D.G. and M., 1995. Quartz textures in epithermal veins, Queensland; classification, origin and implication. Econ. Geol. 90, 1841-1856.

Hyndman, D.W., 1986. Petrology of Igneous and Metamorphic Rocks. Geol. Mag. 123, 88-89. doi: $10.1017 /$ S001675680002673X

Metcalfe, I., 2009. Late Palaeozoic and Mesozoic tectonic and palaeogeographical evolution of SE Asia. Geol. Soc. London, Spec. Publ. 315, 7 23. doi:10.1144/SP315.2

Meyer, C., Hemley, J.J., 1967. Geochemistry of hydrothermal ore deposits. Holt, Rinehart and Winston, New York.

Middlemost, E.A.K., 1994. Naming materials in the magma/igneous rock system. Earth-Science Rev. 37, 215-224. doi:10.1016/00128252(94)90029-9

Mitchell, A.H.G., 1979. Guides to metal provinces in the Central Himalaya collision belt; the value of regional stratigraphic correlations and tectonic analogies. Mem. Geol. Soc. China 3, 167--194.

Mitchell, A.H.G., Ausa, C.A., Deiparine, L., Hlaing, T., Htay, N., Khine, A., 2004. The Modi Taung Nankwe gold district, Slate belt, central Myanmar: Mesothermal veins in a Mesozoic orogen. J. Asian Earth Sci. 23, 321-341. doi:10.1016/S1367-9120(03)00138-X

Mitchell, A.H.G., Chung, S.-L., Oo, T., Lin, T.-H., Hung, C.-H., 2012. Zircon U-Pb ages in Myanmar: Magmatic-metamorphic events and the closure of a neo-Tethys ocean? J. Asian Earth Sci. 56, 1-23. doi:10.1016/j.jseaes.2012.04.019

Myint, T.A., Than, T.N., Min, A., 2014. Precious and Base Metal Mineralization in KwinthonzeNweyon area, Singu and Thabeikkyin Townships, Mandalay Region, Myanmar. Proc. Sundal. Resour. 2014 M GEl Annu. Conv. 343354.

O'Connor, J.T., 1965. A classification of quartz rich igneous rock based on feldspar ratios. US Geol. Surv. 525B, B79-B84.

Pearce, J.A., Harris, N.B.W., Tindle, A.G., others, 1984. Trace element discrimination diagrams for the tectonic interpretation of granitic rocks. J. Petrol. 25, 956-983.

Searle, D.., Haq, B.T., 1964. The Mogok Belt of Burma and Its Relationship to the Himalayan Orogeny. Proc. Int. Geol. Congr. 22, 132-161.

Simmons, S.F., Christenson, B.W., 1994. Origins of calcite in a boiling geothermal system. Am. J. Sci. doi:10.2475/ajs.294.3.361

Swe, W., 1972. A Strike-slip faulting in central belt of Burma [abstr.]. Reg. Conf. Geol. SE Asia, Kuala Lumpur. Annex. Geol. Soc. Malaysia Newsl. 34, 59

Thein, M., Win, S., 1969. The metamorphic petrology, structures and mineral resources of the Shantaung-U-Thandawmywet Range, 
Kyaukse district. Burma Res. Congr. 3, 487514.

Thein, M.L., Myint, O., Kyi, S., Win, H.N., 1990. Geology and stratigraphy of the metamorphosed early Paleozoic rocks of the Mogok- Thabeikkyin- Singu- Madaya Areas. Yangon. 